\title{
Menguatkan Pancasila, Menata Kemajemukan Bangsa
}

\author{
R. Cecep Romli \\ STAI YAPATA AL-JAWAMI, Komplek Al-Jawami No. 87 \\ Sindangsari, Cileunyi, Bandung 40622 \\ ccpromli@gmail.com
}

$\begin{array}{ll}\text { Judul } & \text { : Revolusi Pancasila; Kembali Ke Rel Perjuangan } \\ \text { Penulis } & \text { : Yudi Latif } \\ \text { ISBN } & : 978-979-433-889-6 \\ \text { Tebal } & : \text { xi+216 hlm. } \\ \text { Cetakan } & \text { : I, Juni } 2015 \\ \text { Penerbit } & \text { : Mizan }\end{array}$

Saat ini Indonesia tengah menatap secercah harapan akan pembangunan berkeadilan. Untuk pertama kalinya dalam dua tahun terakhir era reformasi, pembangunan infrastruktur (seperti jalan tol, rel kereta, pelabuhan, bandara dan pembangkit listrik) yang semula terpusat di Jawa digenjot secara merata di seluruh persada Nusantara. Targetnya, agar pertumbuhan ekonomi meningkat secara merata, sehingga menekan jurang ketimpangan.

Seiring dengan itu, gini ratio (ketimpangan pengeluaran) pun mulai ada penurunan. Pada September 2016 gini ratio perkotaan tercatat 0,409 , turun dari gini ratio Maret 2016 sebesar 0,410. Sedangkan gini ratio pedesaan turun dari 0, 327 pada Maret 2016 menjadi 0,316 pada September 2016, menandakan tingkat pemerataan di desa lebih baik dibanding di kota. Kendati masih sangat tipis, menurut Kepala BPS, Suhariyanto, turunnya gini ratio ini karena adanya perbaikan dalam pengeluaran di berbagai daerah dan perbaikan pemerataan pembangunan. (http://www.tribunnews. com/bisnis/2017/02/03/bps-per-aprilangka-gini-ratio-turun-tipis, diakses 5 Juli 2017).

Sungguhpun begitu, akutnya krisis multidimensi tetap menjadi bom waktu yang mengancam. Di tengah kesenjangan yang menganga, merajalelanya korupsi, eksploitasi kekayaan alam oleh kekuatan asing dan para kompradornya, propaganda SARA pun sering menjadi viral yang menerpa persatuan dan kebhinnekaan. Belum lagi, kekuatan hitam koruptor telah berani menyerang penegak hukum KPK, seperti Novel Baswedan.

Sekadar catatan, dalam kurun waktu tahun 2004-September 2016 sudah sebanyak 119 anggota DPR dan DPRD ditangkap KPK karena terjerat korupsi, dan hingga Agustus 2016 sebanyak 18 gubernur dan 343 bupati/walikota terjerat kasus korupsi. Tak heran bila Indeks Persepsi Korupsi Indonesia pada 2016 berada di peringkat 90 dengan skor 37 dari 176 negara. Bandingkan dengan Singapura yang meraih peringkat 7 dengan skor 87, yang merupakan negara di Asia yang dinilai paling bebas korupsi. (https://www.voaindonesia. com/a/indeks-persepsi-korupsi-riturun-/3692750.html, diakses 1 Juli 2017).

Semua ini terjadi secara masif, sistematis, dan terstruktur, sehingga tampaklah bahwa apa yang ada di balik permukaan adalah gurita kekuatan kapitalisme hitam, keserakahan hedonisme dan individualisme. Semua 
adalah kanker krisis yang telah menyerang segala pembuluh darah dan menembus jantung kehidupan. Jika dibiarkan, bukan mustahil kondisi ini akan membawa bangsa ke tubir jurang perpecahan dan kehancuran.

Apa yang harus dilakukan? Buku ini mengungkap pandangan 'diagnostik' Yudi Latif atas endemi krisis bangsa dan solusi yang ia tawarkan. Bagicendekiawan ini, mengingat begitu akutnya krisis dan hanya bisa dipecahkan melalui penjebolan dan penataan ulang pada sistem bernegara, maka hal yang tak dapat dihindarkan lagi adalah: mengobarkan revolusi Pancasila. Pemerintah datang silih berganti, namun cita-cita keadilan sosial tetaplah terbengkalai. "Pilihannya, apakah kita biarkan Indonesia hancur atau bangkit bertempur." (Hal. 8).

Itulah semangat berkobar yang menjiwai buku ini. "Bila saatnya tiba, anak-anak sang zaman tak bisa tahan lagi menghadapi berondongan pelor pertanyaan, 'Mengapa mereka dilahirkan di tanah surga, tapi yang bertumbuh kemiskinan, yang berkembang kesenjangan, yang bersimaharajalela kekacauan, dan yang bertabur adalah bintang-bintang prestasi keburukan?'" (Hal. xi).

\section{Keharusan Revolusi Pelangi di Tanah Surga}

Indonesia adalah sepotong tanah surga, negeri indah permai bagai untaian zamrud yang melilit khatulistiwa. Sejak pra-kolonial kepulauannya dikenal sebagai suatu rangkaian dari "gugus kemakmuran" (belt of prosperity). Kesuburan dan kemakmurannya terpahat dalam ungkapan "Gemah ripah loh jinawi, tata tentrem kerta raharja".

Karena kesuburannya, negeri kepulauan terbesar di dunia ini -terdiri dari 13 ribu pulau besar dan kecil, terentang dari timur sampai barat dengan jarak lebih dari 5 ribu kilometer -- memanggil berbagai suku bangsa berdatangan, berbaur, dan menetap, sehingga akhirnya memuat lebih dari 300 suku bangsa dengan 250 jenis bahasa berbeda. Maka sepotong surga itu bagai sebuah kapal besar dengan penumpangnya yang begitu beragam.

Tetapi oleh penjajah dan penguasa otoriter, nasib sepotong surga itu dibalik menjadi nestapa serpihan neraka. Bukan saja kekayaan alam dikeruk, keragaman dijadikan alat untuk memecah belah dan adu domba, manusia dipecah oleh diskriminasi dan jurang ketimpangan, agama dan budaya direkayasa untuk pelanggengan penjajahan maupun kekuasaan, tetapi juga manusia "dididik" dan dikerdilkan menjadi pengeruk kuasa dan harta dengan cara apa pun. Karena itu bagi Yudi, warisan terburuk dari kolonialisme, feodalisme dan otoritarianisme bukanlah terletak pada besarnya kekayaan yang dirampas, penderitaan yang ditimbulkan serta ribuan nyawa yang melayang --betapapun itu nestapa tak terperikan -- melainkan pada pewarisan nilai-nilai koruptif, penindasan dan perbudakan yang tertanam dalam mental budaya bangsa. (Hal. 99).

Karena "kekalnya" mental itulah, siapa pun tak dapat menutup mata bahwa negeri ini dalam beberapa aspek masih dalam keadaan terjajah. Keragaman yang mestinya menjadi kekayaan untuk saling mengenal, saling menghormati, saling belajar serta saling berbagi dan melayani untuk menguatkan persatuan, malah dijadikan alat pembakar sentimen primordial yang mengarah pada perpecahan. Semangat ketuhanan yang memandang seluruh makhluk adalah manifestasi dari MahakasihNya, yang mestinya dapat menaungi keragaman dan kepentingan umum, 
malah dikerdilkan oleh formalisme dan "egoisme" keagamaan.

Pesta demokrasi berbiaya tinggi dan perluasanpartisipasipolitikyangmestinya meningkatkan budaya pelayanan publik justru merebakkan money politic dan korupsi. Ketika kepentingan minoritas pemodal lebih ampuh mengendalikan politik daripada institusi-institusi publik, maka "demokrasi tidak lagi menjadi sarana efektif bagi kekuatan kolektif untuk mengendalikan kepentingan perseorangan, malahan berbalik arah menjadi sarana efektif bagi kepentingan perseorangan untuk mengontrol institusi dan kebijakan publik; res publica (urusan umum) tunduk di bawah kendali res privata (urusan privat)." (Hal. 5-7). Praktis cita-cita keadilan sosial dijegal oleh keserakahan individualisme.

Maka, kalaulah cita-cita itu benar-benar hendak dicapai, mau tak mau solusinya adalah melanjutkan keberhasilan revolusi kemerdekaan dengan revolusi sosial. Revolusi merebut kemerdekaan berhasil berkat upaya para pejuang bangsa untuk "mempancasilakan revolusi". "Artinya, revolusi kemerdekaan itu didarahi dengan semangat inklusif moral Pancasila melalui pengikatan komitmen bersama dari segenap elemen revolusioner lintas etnis, agama, ideologi, dan kelas sosial." (Hal.14). Maka, menurut Yudi, revolusi sosial pun harus didarahi oleh "kekuatan-kekuatan revolusioner dari segala keragaman posisi subjek dalam masyarakat, baik etnis, agama, ideologi dan kelas sosial”. (Hal. 158).

Namun untuk keberhasilan revolusi sosial, menurut cendikiawan ini, tidaklah cukup dengan "mempancasilakan revolusi" -- dalam arti menjadikan moral Pancasila itu sebagai alat persatuan belaka -- tetapi juga yang paling mendesak adalah dengan "merevolusikan Pancasila". Artinya, Pancasila itu harus menjadi praksis-ideologis yang berdaya dobrak terhadap segala kendala "mental-material-politikal" sehingga (mulai) terwujudlah keadilan sosial yang dicita-citakan itu. (Hal. 14). Memang masyarakat yang sudah merdeka tidak lagi dapat dijalin erat oleh kenyataan satu tanah air belaka, tetapi juga harus diyakinkan dengan satu cita-cita riil menuju kesetaraan dan kesejahteraan bersama.

Keyakinan itu tumbuh bukan sekadar lewat komunikasi kata, tetapi yang terpenting adalah keteladanan para pemimpin dan bukti-bukti kebijakan yang dirasakan riil oleh masyarakat. Atas bukti dan keyakinan itulah, masyarakat dari berbagai elemen akan bersatu menggalang "revolusi pelangi" demi keadilan sosial.

\section{Tanah Tumpah Darah Semua}

Apa yang digarisbahawi cendikiawan ini, di mana revolusi kemerdekaan itu berhasil karena didarahi oleh segenap elemen bangsa, memang merupakan fakta sejarah yang tak bisa diingkari. Sejarah mencatat, dari 168 pahlawan nasional, 18 persennya adalah dari kalangan non Muslim. Dari non Muslim misalnya dikenal pahlawan Simatupang, Johannes Latuharhary, Sam Ratulangi, Wolter Monginsidi, Pattimura, Todung Sutan Gunung Mulia, Johannes Leimena, Yos Sudarso, Alexander Jacob Patty, dan sebagainya. (https://tirto.id/ pengikut-kristus-untuk-kemerdekaanindonesia-bDjw, diakses 5 April 2017).

Sebelum lahirnya NKRI (Negara Kesatuan Republik Indonesia) pada 17 Agustus 1945, rasa satu bangsa dari aneka ragam suku dan agama seseantero Nusantara telah lahir terlebih dulu. Eksistensi rasa satu bangsa itu hampir dua daSaw.arsa mendahului lahirnya NKRI, yaitu sejak awal abad 20 saat gelora pergerakan kemerdekaan membangkitkan seluruh rakyat. 
Bahkan sebelum lahirnya pergerakan kemerdekaan, bagi sebagian (kecil) rakyat Nusantara yang sudah punya kesadaran sejarah, tentunya kebangsaan Nusantara telah eksis jauh sebelum kedatangan Belanda, yaitu sejak kepulauan Nusantara dipersatukan oleh kerajaan Sriwijaya dan Majapahit. Ribuan pulau Nusantara itu direkatkan oleh bendera politik tunggal maupun budaya Bhinneka Tunggal Ika. Inilah yang oleh Nurcholish Madjid disebut nasionalisme klasik di bumi Nusantara (Madjid, 2003: 7-21).

Tentunya sebagian rakyat itu sudah memahami bahwa nasionalisme klasik itu mencakup tidak hanya satu etnik melainkan aneka suku dan agama yang hidup di Nusantara. Dalam bahasa modern, nasionalisme Nusantara bukanlah kebangsaan etnik (ethnic nasionalism) yang hanya mengakui satu etnik atau satu agama, melainkan sudah merupakan benih dari nasionalisme "modern" (modern/civic nasionalism) yang mencakup dan mengakui seluruh suku dan agama di dalamnya.

Berabad-abad lamanya kehidupan multikultural yang damai sudah terkandung di dalam bumi Nusantara, yang kemudian falsafahnya pada awal abad 14 diabadikan oleh Mpu Tantular dalam semboyan Bhinneka Tunggal Ika, Tan Hana Dharmma Mangrwa: "Berbeda-beda Namun Satu, Tiada Kebenaran Bermuka Dua. Menurut Garry Van Klinken, sebagaimana dikutip tirto.id, bahkan sebelum Borobudur selesai dibangun 26 Mei 824, sudah ada orang-orang Kristen di sekitar pantai Sibolga, sisi pantai barat Sumatera Utara, di sana ada gereja yang dibangun Kristen Nestorian dari Persia. Artinya, Kristen sudah ada di Nusantara jauh sebelum kedatangan Portugis dan Belanda. (https://tirto.id/pengikutkristus-untuk-kemerdekaan-indonesiabDjw, diakses 5 April 2017).
Ketika penjajah datang, tentunya setiap agama dan suku tak rela tanahnya dijajah dan injak-injak, sehingga seluruh rakyat dari agama dan suku apa pun memusuhi penjajahan. Kehadiran musuh bersama itu mengobarkan rasa satu tanah air yang sudah ada. Maka, perlawanan terhadap penjajah pun berkobar bukan hanya dari satu agama dan suku melainkan dari ragam agama.

Itulah yang dirasakan Bung Karno saat menyaksikan di daerah mana pun yang beliau kunjungi banyak taman pahlawan. Dalam pidatonya di Surabaya, 24 September 1955, Bung Karno mengatakan,

\begin{abstract}
"Aku melihat di daerah-daerah yang kukunjungi, di manapun aku datang, aku melihat Taman-taman Pahlawan. Bukan saja di bagian yang beragama Islam, tetapi juga di bagian yang beragama Kristen. Aku melihat Taman-taman Pahlawan di mana-mana. Di Surabaya, pada tanggal 10 November tahun 1945, siapa yang berjuang di sini? Segenap pemuda-pemudi, kiai, kaum buruh, kaum tani, segenap rakyat Surabaya berjuang dengan tiada perbedaan agama, adat-istiadat, golongan atau suku." (https://pancasilakoe. wordpress.com/2012/04, diakses 6 April 2017).
\end{abstract}

\section{"Revolusi" Ketuhanan Yang Berperikemanusiaan}

Buku ini mengelaborasi apa itu Revolusi Pancasila, apa sifat, landasan, dan teori Revolusi Pancasila, apa saja modal material, mental, dan politikal Revolusi Pancasila serta program-programnya. Namun, hingga bagian penutup tidak ditemukan penjelasan gambaran konkret siapa atau karakter seperti apa yang disebut sebagai "kekuatan-kekuatan revolusioner dari segala keragaman posisi subjek dalam masyarakat (etnis, agama, ideologi dan kelas sosial)", yang

Jurnal Multikultural \& Multireligius Vol. 16 No. 1 
harus dibangkitkan dan digalang demi "memenangkan revolusi Pancasila". (Hal. 158). Padahal, bukankah tanpa gambaran konkret siapa pelakunya cetusan api revolusi Pancasila ini terasa mengambang atau kurang membumi? Di ujung Penutup hanya disebutkan, untuk menjalankan revolusi Pancasila, "diperlukan kebesaran jiwa yang teguh pendirian dan berani menyimpang dari mainstream. Jiwa profetis-patriotis, yang berani membiasakan yang benar, bukan membenarkan yang biasa; jiwa profetispatriotis yang tidak lekas putus asa dalam menahan cobaan dan gempuran; jiwa profetis-patriotis yang sanggup menyatukan satuan-satuan lidi pecutan ke dalam satu kebersamaan gempuran yang dapat melenyapkan krisis dan penyakit sosial." (Hal. 208). Namun, bagaimana karakter dan gambaran konkret mereka itu?

Dalam konteks ini, selayaknya buku ini dibaca sebagai lanjutan dari buku kedua "trilogi" karya Yudi Latif tentang Pancasila, berjudul Mata Air Keteladanan; Pancasila dalam Perbuatan (2014). Buku inilah yang memuat banyak teladan atau karakter konkret yang dimaksud. Sedangkan buku pertama berjudul Negara Paripurna; Historitas, Rasionalitas, dan Aktualitas Pancasila (2011), mengkaji Pancasila sebagai paradigma pengetahuan. Buku ini pun perlu dipandang sebagai dasar ilmiah bagi buku ketiga. Karena kendati buku ketiga juga menjabarkan dasar teori revolusi Pancasila di tengah kancah teoriteori sosial (Hal. 87-99), namun tentunya buku pertama merupakan fondasi yang lebih luas dan kokoh.

Buku kedua tersebut merupakan respon Yudi atas keluhan luas mengenai krisis keteladanan dan sulitnya menyemaikan moral pancasila melalui teladan nyata. Mengingat Pancasila adalah pandangan hidup bangsa dan ideologi negara, maka tokoh-tokoh teladan yang dikisahkan pun diusahakan sebisa mungkin mewakili segala keragaman Indonesia, dari segi agama, etnis, kelas sosial, jenis kelamin maupun wilayah. Mutiara pesan moral bertaburan di balik banyak peristiwa yang dialami tokoh-tokoh itu, seperti bintang-bintang yang gemerlapan di langit keragaman, sehingga buku yang setebal 680 halaman ini jauh dari rasa menjemukan.

Syahdan, sampai menjelang akhir dekade 1950-an, Prawoto Mangkusasmito belum juga punya rumah. Tokoh Partai Masyumi dan Muhammadiyah yang pernah menjadi Wakil Perdana Menteri (2 April 1952 - 31 Juli 1953) dan Wakil Ketua I Konstituante (10 November 19565 Juli 1959) itu memang dikenal sebagai pribadi yang sederhana. Di tengah suasana perbedaan pandangan politik yang tajam menyangkut Dasar Negara di Konstituante, I.J. Kasimo, Ketua Partai Katolik, tidak kehilangan belas kasihnya. Mengetahui Pak Prawoto hendak membeli rumah yang sudah lebih dari enam tahun disewanya (sejak 1952), Pak Kasimo merasa tergerak hatinya untuk memberikan bantuan. Kebetulan pemilik rumah itu adalah seorang suster Katolik keturunan Tionghoa, Tan Kin Liang. Ia pun membantu Pak Prawoto "merayu" pemilik rumah yang tinggal di Maastrich, Belanda itu, hingga akhirnya rumah yang terletak di jalan Kertosono Jakarta itu pun bisa dibeli Pak Prawoto pada 20 Maret 1959. Bahkan, menurut sumber lain, Pak Kasimo pun ikut mengumpulkan dana untuk membantu pembelian rumah tersebut.

Demikianlah salah satu contoh kisah teladan dalam buku kedua, Mata Air Keteladanan; Pancasila dalam Perbuatan, yang bersumber dari Bajasut \& Hakiem (2014: 35-36) dan juga cerita K.H. Abdurrahman Wahid (Gus Dur) secara lisan (Latif, 2014: 2). Kisah persaudaraan yang menjalin dua tokoh dengan corak 
keagamaan dan politik yang berbeda itu nyata menggambarkan semangat ketuhanan yang berperikemanusiaan, penuh kasih sayang, lapang dan toleran.

Dalam hal ini, teringatlah kita akan mutiara pesan Hatta tentang sila Ketuhanan yang beruntai dengan sila kemanusiaan,

"Masing-masing golongan bisa memahami arti Ketuhanan Yang Maha Esa itu menurut paham agamanya. Tetapi, nyatalah bahwa inti dari Ketuhanan Yang Maha Esa itu ialah penghargaan manusia sebagai makhluk Tuhan. Jikalau di antara manusia dengan manusia tidak ada harga-menghargai, maka tidak bisa dicapai suatu susunan dunia. Di antara manusia ada yang kaya ada yang miskin, ada yang berbeda kecakapannya, ada yang bodoh ada yang pintar, tetapi sebagai manusia makhluk Tuhan ia dipandang sama." (Latif, 2014: 35).

Ketuhanan itu pula yang membuat Baharuddin Lopa, seorang religius kelahiran Polewali Mandar, 27 Agustus 1935, bersih dan teguh pendirian. Sejak menjabat Bupati Majene pada usia 25 tahun, Lopa gigih menentang seorang komandan battalion yang terkenal kaya karena melakuan penyelundupan. Suatu saat Lopa hendak membeli mobil, yang harga pasarnya saat itu Rp 30 juta, pemilik dealer mobil menawarkan harga khusus untuk Lopa, yaitu Rp 25 juta. Lopa menolak. Jaksa lurus dan sederhana ini tidak mau diperlakukan istimewa seperti itu, dan ia meminta agar membeli mobil sesuai harga pasar. Kalaupun hendak diberi diskon, diskonnya yang wajar. Mobil tersebut akhirnya diberi sang jaksa pemberani dan hanya takut kepada Allah itu dengan harga Rp 27 juta, dengan cara mencicil (Latif, 2014: 113-114).

\section{Revolusi Nirkekerasan}

Melalui dua contoh kisah teladan ini, jelas bahwa dalam kancah revolusi sosial, yang diperlukan bukannya senjata melainkan keberanian dan teguh pendirian. Dalam buku ini pun Yudi menjelaskan bahwa kekerasan bukanlah esensi dari revolusi. Pada mulanya revolusi merupakan istilah dalam sains. Istilah ini berarti suatu ketetapan (konstanta) yang berlangsung dalam perubahan, seperti terkandung dalam frasa "revolusi planet dalam orbit". Dalam perkembangan selanjutnya, revolusi mengandung arti "suatu perubahan struktur mental dan keyakinan karena adanya introduksi gagasan dan tatanan baru yang membedakan dirinya dari gagasan dan tatanan masa lalu".

Pengertian revolusi seperti itulah yang kemudian diadopsi oleh wacana dan gerakan sosial politik. Penggunaan istilah revolusi dalam politik menjadi populer menyusul Revolusi Amerika (1776) dan terlebih setelah revolusi Perancis (1789). Namun seperti halnya pengertian revolusi dalam sains, revolusi dalam politik pun pada mulanya mengandung konotasi yang ramah (benign), hingga Revolusi Perancis berubah menjadi ekstrem dan penuh teror. Bagaimanapun, revolusi tidak mesti dengan kekerasan. Seperti suatu bentuk revolusi nirkekerasan yang dijelaskan dalam buku The Capitalist Revolution karya Peter L. Berger (Berger, 1986, 20-21).

\section{Tantangan Intoleransi dan Diskriminasi}

Revolusi Pancasila berarti "suatu ikhtiar perubahan mendasar secara akseleratif pada sistem sosial, yang meliputi ranah material, mental, dan politik, berlandaskan prinsip-prinsip Pancasila, dalam rangka mewujudkan perikehidupan kebangsaan dan kewargaan yang merdeka, bersatu,

\begin{tabular}{l|l} 
Jurnal Multikultural \& Multireligius Vol. 16 & No. 1
\end{tabular} 
berdaulat, adil, dan makmur, baik secara material maupun spiritual". (Hal. 57).

Dalam kerangka revolusi Pancasila, pada ranah relasi-ideologi, sasaran sila ke-1,2 dan 3 adalah terbentuknya "masyarakat yang religius berperikemanusiaan, egaliter, mandiri, amanah, tak memuja materialis-hedonisme; menjalin persatuan dengan semangat pelayanan." Sedangkan para ranah relasi-produksi, sasaran sila ke-5 adalah terwujudnya "perekonomian merdeka yang berkeadilan dan berkemakmuran, berlandaskan tolong-menolong, menekankan penguasaan negara (atas sektor strategis) seraya memberi peluang bagi hak milik pribadi dengan fungsi sosial."

Sedangkan pada ranah agen politik, yang mencakup dua ranah sebelumnya, sasaran sila ke-4 adalah "konsentrasi kekuatan nasional melalui demokrasi permusyawaratan yang berorientasi persatuan (negara kekeluargaan) dan keadilan (negara kesejahteraan)".

Akhirnya, semua sasaran itu bermuara pada satu tujuan (cita-cita): "Terwujudnya perkehidupan kebangsaan dan kewargaan yang merdeka, bersatu, berdaulat, adil dan makmur berdasarkan Pancasila". (Hal. 98)

Dari kerangka ini, jelas bahwa untuk mencapai satu tujuan itu harus ditopang oleh terbentuknya mental masyarakat religius berperikemanusiaan dan egaliter serta amanah; dan secara bersamaan oleh perekomian yang merdeka (independen) yang berkeadilan dan berkemakmuran. Tanpa dua syarat penopang ini, yang bersifat kultur sekaligus struktur, maka amat jauhlah untuk dapat mencapai kewargaan yang setara sekaligus sejahtera itu.

Tak dapat dipungkiri bahwa tercapainya iklim religius yang egaliter dan toleran itu masih jauh pangang dari api. Justru ketika era reformasi membuka kebebasan dan perluasan partisipasi politik, yang merebak bukan saja korupsi tapi juga radikalisasi dan primordialisasi berdasar sentimen agama tertentu, yang berujung pada meruyaknya inteloleransi dan diskriminasi.

Penelitian Wahid Institute menemukan, pelanggaran kebebasan beragama dan tindak intoleransi meningkat dari tahun 2009-2011. Pelanggaran kebebasan beragama pada tahun 2009 sebanyak 34 kasus. Jumlah ini naik menjadi 63 kasus pada tahun 2010 dan naik lagi menjadi 93 kasus pada tahun 2011. Sedangkan tindak intoleransi pada tahun 2009 sebanyak 93 kasus. Jumlah ini naik menjadi 133 kasus pada tahun 2010 dan naik lagi menjadi 184 kasus pada tahun 2011. Yang dimaksud pelanggaran kebebasan beragama adalah tindakan penghilangan, pembatasan atau pengurangan hak dan kebebasan dasar setiap orang untuk berpikir, berkeyakinan dan beragama yang dilakukan oleh negara. Sedangkan tindakan intoleransi adalah sikap dan tindakan yang tidak menghargai hak-hak fundamental pemeluk agama tertentu dalam menjalankan keyakinan agama yang berbeda dengan keyakinannya yang dilakukan oleh individu atau kelompok masyarakat.

Pada tahun 2011, hampir separuh dari pelanggaran kebebasan beragama (oleh aparatur negara) adalah berupa pelarangan atau pembatasan rumah ibadah (49 kasus atau 48\%); intimidasi atau kekerasan sebanyak 20 kasus atau $19,6 \%$ dan pembiaran kekerasan sebanyak 11 kasus atau 10,8\%. Menurut data tahun 2011 ini, aparat yang paling banyak melakukan pelanggaran adalah aparat kepolisian (sebanyak 32 kasus atau 26,2 \%), Pemkab/Pemkot sebanyak 28 kasus atau 23,0\%, tentara sebanyak 16 kasus atau 13,1\%, Satpol PP sebanyak 10 kasus atau 8,2 \%. 
Sedangkan tindak intoleransi (oleh individu atau kelompok masyarakat) yang paling banyak terjadi pada 2011 adalah intimidasi dan ancaman kekerasan pada penganut agama atau keyakinan lain (48 kasus atau 24,6\%), pernyataan dan penyebaran kebencian pada agama dan keyakinan lain sebanyak 27 kasus atau $13,6 \%$, dan perusakan properti kelompok agama sebanyak 27 kasus atau 13,8\%, diskriminasi atas dasar agama sebanyak 26 kasus (13,3\%), dan penolakan rumah ibadah agama lain sebanyak 14 kasus $(7,2 \%)$. Pelaku intoleransi yang paling banyak adalah FPI sebanyak 38 kasus atau $17,8 \%$, kelompok masa terorganisir sebanyak 33 kasus atau $15,5 \%$, masa tidak teridentifikasi sebanyak 19 kasus atau $8,9 \%$, MUI sebanyak 17 kasus atau 8,0\%, dan seterusnya. (Denny J.A, 2014: 49-55).

Data penelitian Wahid Institute ini dikonfirmasi oleh data survei dari Lingkaran Survei Indonesia (LSI) pada tahun 2010. Hanya 51,9\% masyarakat Indonesia yang bisa menerima kalau di lingkungan mereka didirikan rumah ibadah agama lain. Mayoritas publik $(75,6 \%)$ memang menyatakan mereka tidak masalah dan bisa menerima tetangga yang beda agama, namun ada $22,6 \%$ publik yang tidak bisa menerima. Sebanyak 55\% publik Indonesia bisa menerima jika kepala pemerintahan berasal dari agama yang berbeda. Namun dalam jumlah besar $(38,8 \%)$ publik tidak dapat menerima kalau pemerintahan dipimpin oleh orang yang berbeda agama.

Hasil survei Lingkaran Survei Indonesia (LSI) ini tidak jauh berbeda dengan hasil survei Lembaga Survei Indonesia tahun 2006. Dalam survei Lembaga Survei Indonesia, 36,7\% publik Indonesia keberatan kalau penganut agama lain mengadakan acara keagamaan di wilayah sekitar. Dan sebanyak 42,3\% keberatan kalau di lingkungan mereka dibangun rumah ibadah agama lain $(7,2 \%)$ (Denny J.A, 2014).
Terkait masalah ini, yang menarik dari buku karya Yudi Latif ini adalah kenyataan bahwa yang disebut sebagai musuhrevolusiPancasila--selain tentunya kapitalismehitam dan sebagainya --bukan hanya "unsur-unsur fudamentalisme (ekstrimisme) keagamaan", tapi juga "unsur-unsur fundamentalisme sekuler yang anti-theis/agama (h.176). Artinya, yang "kanan" maupun yang "kiri" samasama dipandang bisa saja melakukan intoleransi dan diskriminasi. Inilah moderasi dan sikap berimbang dari buku ini.

Yang juga menarik disoroti, mengapa sebagian Muslim keberatan bertetangga dengan non Muslim, padahal Nabi Saw. dan para sahabatnya Ra. telah memberikan contoh bagaimana bertetangga yang mulia dan luhur dengan non Muslim (Yaqub, 2000: 70-72)? Mengapa sebagian Muslim keberatan terhadap pendirian rumah ibadah agama lain, padahal Nabi Saw. dan para sahabatnya Raa menjunjung tinggi dan sangat menghormati rumah ibadah agama lain? Satu-satunya yang ada dasarnya adalah sikap tidak menerima pemimpin non Muslim, karena memang menurut sejumlah ulama hal ini dilarang, namun larangan ini pun secara keilmuan murni dan kerendahhatian tidak boleh dimutlakkan karena ada juga sejumlah ulama yang membolehkan. (Qardhawi, 1992: 23-26).

Dari sini jelas bahwa kekurangkenalan sebagian (kecil) Muslim terhadap ajaran agama ikut menyumbang masalah intoleransi dan diskriminasi yang pada gilirannya menjadi masalah bangsa dan Pancasila. Dalam hal ini patut menjadi perhatian bersama apa yang dijelaskan oleh Nurcholish Madjid bahwa kesulitan sebagian Muslim -- yang berjasa namun termarjinalisasikan oleh penjajah -- juga menjadi kesulitan seluruh bangsa dan negara. Persoalan bangsa dan negara tidak akan selesai jika persoalan mereka 
tidak terselesaikan (Madjid, 2003: 21). Dari sini Madjid pun menekankan pentingnya peningkatan dan pemerataan pendidikan, termasuk pendidikan agama (Madjid, 2003: 121-133).

\section{Islam, Pancasila, dan Kemajemukan}

Presidan Soekarno sering mengatakan bahwa dirinya bukanlah pencipta Pancasila, melainkan penggali Pancasila. Ketika Bung Karno menggali mutiara Pancasila dari agama dan budaya yang terkandung berabad-abad lamanya dalam bumi Nusantara --untuk menjadi dasar falsafah dan ideologi integralistik yang mengatasi partikularitas paham perseorangan dan golongan -- bisa pahami bahwa salah satu sumber yang digalinya itu, dengan jiwa Bung Karno yang Islami, bukanlah Islam yang telah disingkirkan dan direkayasa oleh penjajah dengan "otak" Snouck Hurgronje; melainkan Islam "bahari" dari masa prakolonial. Secara tipologi katakanlah itu Islam "intrinsik", "transenden" atau "profetis" yang bersahabat dengan agama lain dan berbaur dengan al-ma'ruf atau kearifan lokal.

Bagi Bung Karno, hasil penggaliannya itu sebenarnya merupakan pemberian Tuhan kepada dirinya. Tentang betapa mendalam keislaman Bung Karno dalam proses kreasi menggali Pancasila, tampak dari cerita Bung Karno pada Peringatan Hari Lahirnya Pancasila, 1 Juni 1964:

“...Malah pernah saya katakan, bahwa sebenarnya hasil - atau lebih tegas penggalian dari Pancasila ini - adalah pemberian Tuhan kepada saya.... Sesudah Dokuritsu Zyunbi Tyoosakai itu bersidang beberapa hari lamanya, sesudah berpuluh-puluh anggota dari Dokuritsu Zyunbi Tyoosakai itu berpidato, akhirnya datanglah giliran saya. Ditentukan oleh Ketua dari Dokuritsu Zyunbi Tyoosakai itu, bahwa saya keesokan harinya akan mendapat giliran berbicara. Berbicara memberi jawaban atas pertanyaan, apakah dasar yang hendak kita pergunakan untuk meletakkan negara Indonesia Merdeka di atasnya.

Didalam pidato beberapa waktu lalu di Senayan itu, saya telah ceritakan, pada satu tengah malam yang keesokan harinya saya diharuskan mengucapkan pidato, saya keluar dari rumah Pegangsaan Timur 56 yang sekarang tempat dari Gedung Pola. Saya keluar di malam yang sunyi itu dan saya menengadahkan wajah saya ke langit, dan saya melihat bintang gemerlapan ratusan, ribuan, bahkan puluhan ribu. Dan di situlah saya merasa kecilnya manusia, di situlah saya merasakan dha'ifnya aku ini, di situlah aku merasa pertanggungan jawab yang amat berat dan besar diletakkan di atas pundak saya, oleh karena keesokan harinya saya harus mengemukakan usul saya tentang hal dasar apa negara Indonesia Merdeka harus memakai.

Pada saat itu dengan segenap kerendahan hati saya memohon kepada Tuhan Yang Maha Esa. "Ya Allah, ya Robbi, berikanlah petunjuk kepadaku. Berikanlah petunjuk apa yang besok pagi akan kukatakan, sebab Engkaulah ya Tuhanku, mengerti bahwa apa yang ditanyakan kepadaku oleh Ketua Dokuritsu Zyunbi Tyoosakai itu bukan barang yang remeh, yaitu dasar daripada Indonesia Merdeka. Dasar daripada satu negara yang telah diperjuangkan oleh seluruh Rakyat Indonesia berpuluhpuluh tahun dengan segenap penderitaannya, yang penderitaanpenderitaan itu aku sendiri telah melihatnya. Dasar daripada Negara 
Indonesia Merdeka yang menjadi salah satu unsur daripada Amanat Penderitaan Rakyat. Aku, ya Tuhan telah Engkau beri kesempatan melihat penderitaan-penderitaan rakyat untuk mendatangkan Negara Indonesia yang merdeka itu. Aku melihat pemimpin-pemimpin, ribuan, puluhan ribu, meringkuk di dalam penjara. Aku melihat rakyat menderita. Aku melihat orangorang mengorbankan ia punya harta benda untuk tercapainya cita-cita itu. Aku melihat orangorang didrel mati. Aku melihat orang naik tiang penggantungan. Bahkan pernah menerima surat daripada seorang Indonesia yang keesokan harinya akan naik tiang penggantungan. Dalam surat itu dia mengamanatkan kepada saya sebagai berikut: "Bung Karno, besok aku akan meninggalkan dunia ini. Lanjutkanlah perjuangan kita ini." Ya Tuhan, ya Allah, ya Robbi, berilah petunjuk kepadaku, sebab besok pagi aku harus memberi jawaban atas pertanyaan yang maha penting ini!"

Saudara-saudara, setelah aku mengucapkan doa kepada Tuhan ini, saya merasa mendapat petunjuk. Saya merasa mendapat ilham. Ilham yang berkata, "Galilah apa yang hendak engkau jawabkan itu dari bumi Indonesia sendiri." Maka malam itu aku menggali, menggali di dalam ingatanku, menggali di dalam ciptaanku, menggali di dalam khayalku, apa yang terpendam di dalam bumi Indonesia ini, agar supaya hasil dari penggalian itu dapat dipakainya sebagai dasar daripada Negara Indonesia Merdeka yang akan datang." (Latif, 2011: 12-14/ http:// dapur.sukarno.org/di-atas-dasarpancasila-rakyat-indonesia-tetapbersatu, diakses 6 April 2017).
Dilihat dari proses kerasi penggaliannya yang religius ini, maka Pancasila sebagai hasil penggalian itu bukan saja cocok dengan Islam melainkan juga bersumber dari kesadaran Islam itu sendiri. Meminjam ungkapan seorang kiai, Pancasila adalah ibarat gula yang disarikan dari agama yang seumpama tebu. ${ }^{1}$ Pancasila disarikan oleh Bung Karno dari Islam dan agama lainnya yang ia persembahkan untuk menaungi seluruh anggota bangsa yang multiagama dan multibudaya (Latif, 2017).

Maka, apa yang menjadi ketentuan Pancasila dan Konsitusi misalnya tentang netralitas negara terhadap semua agama dapatlah dipandang tidak sebatas sebagai hukum negara (yang dipaksakan pada komunitas agama), tapi sebaliknya merupakan aspirasi nilai dari Islam juga. Sehingga apa yang ditegaskan oleh buku kedua, bahwa negara harus berjarak yang sama terhadap semua agama, serta oleh buku ini, bahwa "meski Pancasila tidak bermaksud mengintervensi pengembangan moral privat dan komunitas (agama), namun bisa mencegah secara hikmat-bijaksana pengembangan moral privat dan komunitas yang dapat membahayakan kehidupan publik", (Hal. 38) apa yang ditegaskan ini dapatlah diterima sebagai bersumber dari rahim pandangan Islam (dalam bergaul dengan agama lain).

Namun, semua ini secara sosiologis bergantung pada seberapa merata Islam "profetis" bersemai dalam dada umat Islam. Dengan kerangka inilah, komunitas Islam dan komunitas agama lainnya dapat bersatu menggalang kekuatan untuk ikut memupus berbagai penyakit sosial demi pencapaian kesetaraan dan kesejahteraan bersama. Seperti yang diimpikan oleh buku ini, "...Jiwa profetis-patriotis yang sanggup menyatukan satuan-satuan

1 Ungkapan seorang kiai kepada Yudi Latif saat remaja, yang terungkap saat Seminar Agama dan Penguatan Nilai-nilai Pancasila yang diselenggarakan Puslitbang Bimas Agama dan Layanan Keagamaan Kementerian Agama RI, 19 Juni 2017.

Jurnal Multikultural \& Multireligius Vol. 16 $\mid$ No. 
lidi pecutan ke dalam satu kebersamaan gempuran yang dapat melenyapkan krisis dan penyakit sosial." (Hal. 208).

Akhirnya, buku ini (beserta dua buku sebelumnya) menempati posisi yang sangat penting dalam khazanah wacana Pancasila umumnya, serta wacana agama dan Pancasila khususnya. Ketiganya merupakan sumbangan karya intelektual sekaligus suara moral yang besar artinya bagi masa depan bangsa Indonesia.

\section{Daftar Pustaka}

J.A., Denny, Menjadi Indonesia Tanpa Diskriminasi, Jakarta: inspirasi.co, 2014.

Latif, Yudi, Revolusi Pancasila; Kembali Ke Rel Perjuangan, Jakarta: Mizan, 2015. Mata Air Keteladanan; Pancasila Dalam Perbuatan, Jakarta: Mizan, 2014.

Negara Paripurna; Historitas, Rasionalitas, dan Aktualitas Pancasila, Jakarta: Gramedia, 2011.

Madjid, Nurcholish, Indonesia Kita, Jakarta: Universitas Paramadina, 2003.

Natsir, Muhammad, The Indonesian Revolution, dalam Kurzman, Charles, Liberal Islam, New York: Oxford University Press, 1998.

Qardhawi, Yusuf, Ghair al-Muslimin fi al-Mujtama' al-Islami, Mesir: Maktabah Wahbah, 1992.

Steenbrink, Karel, Pancasila as an Ambiguous Instrument for Interreligious Harmony And Development in Indonesia, 1945-2015.

Yaqub, Ali Mustafa, Kerukunan Umat Dalam Perspektif Al-Quran dan Hadis, Jakarta: Pustaka Firdaus, 2000.

\section{Internet:}

http://www.tribunnews.com/bisnis/2017/02/03/bps-per-april-angka-gini-ratio-turuntipis,diakses 5 Juli 2017

https://www.voaindonesia.com/a/indeks-persepsi-korupsi-ri-turun-/3692750.html, diakses 1 Juli 2017.

https://tirto.id/pengikut-kristus-untuk-kemerdekaan-indonesia-bDjw, diakses 5 April 2017

https://pancasilakoe.wordpress.com/2012/04, diakses 6 April 2017

http://dapur.sukarno.org/di-atas-dasar-pancasila-rakyat-indonesia-tetap-bersatu, diakses 6 April 2017

Sumber Internet:

http://nasional.kompas.com/read/2016/09/05/17561821/ketua.kpk.sudah.119.anggota

http://www.koran-jakarta.com/korupsi-tiada-henti/ 